\title{
Favorable in vitro effects of combined IL-12 and IL-18 treatment on NK cell cytotoxicity and CD25 receptor expression in metastatic melanoma patients
}

Katarina Mirjačić Martinović ${ }^{*}$, Nada Babović², Radan Džodić ${ }^{3,4}$, Vladimir Jurišić $^{5}$, Suzana Matković ${ }^{2}$ and Gordana Konjević 1,4 $^{-1}$

\begin{abstract}
Background: As IL-12 and IL-18 have important immunostimulatory role the aim of this study was to investigate their in vitro effects on functional and receptor characteristics of NK cells and their subsets in healthy controls (HC) and metastatic melanoma patients (MM).

Methods: Peripheral blood mononuclear cells (PBMC) of HC and MM were stimulated with culture medium alone, medium supplemented with IL-12 $(10 \mathrm{ng} / \mathrm{ml}), \mathrm{IL}-18(100 \mathrm{ng} / \mathrm{ml})$ and their combination. NK cell activity was determined using radioactive cytotoxicity assay, while perforin, CD107a and pSTAT-4 expression, IFN- $\gamma$ production and the expression of NKG2D, DNAM-1, CD161, CD158a/b, CD25, IL-12R beta 1/2 receptors on $\mathrm{CD}^{-} \mathrm{CD}^{-} 6^{+} \mathrm{NK}^{-}$ cells and their $\mathrm{CD}^{-} \mathrm{CD}^{\mathrm{dim}+}$ and $\mathrm{CD}^{-} \mathrm{CD}^{\mathrm{di}} 6^{\text {bright+ }}$ subsets were analyzed by flow cytometry. Cytokine induced level of DAP10 in PBMC was analyzed by reverse transcription polymerase chain reaction.

Results: IL-12 alone or in combination with IL-18 significantly induced NK cell activity and CD107a degranulation marker expression in MM and HC, while IL-18 alone did not have any effect in patients. The combination of IL-12 and IL-18 significantly increased mean fluorescence intensity (MFI) of IFN- $\gamma$ in all NK cell subsets in $\mathrm{HC}$ and only in the bright subset in MM. MM that belong to M1c group with metastasis in liver and increased LDH serum values had significantly lower increase in NK cell cytotoxicity after combined IL-12 and IL-18 treatment compared to the patients in M1a and M1b categories. These results could be explained by decreased IL-12R expression and lower increase in PSTAT-4 and perforin expression in NK cells of M1c patients after IL-12 and combined IL-12 and IL-18 treatment. IL-18 alone significantly decreased NKG2D receptor expression and level of DAP10 signaling molecule in MM, while combined IL-12 and IL-18 increased the expression of CD25 on all NK cell subsets in HC and MM. Additionally, MM that belong to M1a + M1b group had significantly higher increase in CD25 receptor expression compared to the patients in M1c group.
\end{abstract}

Conclusions: The novel data obtained in this study support the use of IL-12 and IL-18 in combination for developing new therapeutic strategies for metastatic melanoma especially for patients with better survival rate and prognosis.

Keywords: IL-12/LL-18, Metastatic melanoma, NK cell cytotoxicity, NKG2D, CD25

\footnotetext{
*Correspondence: kmirjacic@sezam.net

'Department of Experimental Oncology, Institute of Oncology and Radiology

of Serbia, Pasterova 14, 11000 Belgrade, Serbia

Full list of author information is available at the end of the article
} 


\section{Background}

Human natural killer (NK) cells are important components of the innate immune system that are able to lyse transformed cells without prior sensitization. They exert cytotoxic function by releasing perforin and granzymes from their granules and have an immunoregulatory role by producing many cytokines especially IFN- $\gamma$ that regulate adaptive T-cell-mediated anti-tumor response [1]. CD107a, the main membrane molecule of cytolytic granules of NK cells is strongly upregulated on the surface of these cells after their contact with tumor and its expression is associated with perforin release. In this sense, CD107a has been described as a marker of NK cell degranulation and cytotoxicity [2].

The balance between NK cell activating and inhibitory signals mediated by various receptors regulates NK cell effector functions [3]. The most important activating NK receptors are NKG2D, natural cytotoxicity receptors (NCR) and DNAX accessory molecule-1 (DNAM-1). NKG2D, as the most prominent activating c-lectin-like receptor, mediates immune responses that are beneficial in the surveillance against cancer [4]. This receptor upon binding to stress induced ligands constitutively expressed on transformed cells such as MHC-class-I-related molecules, MICA/MICB and ULBP1-4, induces NK cell cytotoxicity in association with DAP10 adaptor molecule [5]. DNAM1 is a co-receptor expressed by virtually all NK cells and its stimulation by interaction with the members of the nectin family, PVR (CD155) and Nectin-2 (CD112), on tumor cells leads to NK cell activation and target cell lysis [6]. Another common NK cell receptor, CD161, one of the earliest markers in NK cell development, is primarily described as an activating receptor [7].

Contrary to this, killer immunoglobulin-like receptors (KIRs) that belong to the immunoglobulin superfamily are responsible for the inhibition of NK cell-mediated lysis of normal cells that express MHC-I molecules. In this sense, according to the "missing-self" hypothesis, the activation of NK cells occurs in contact with malignantly transformed cells that have lost MHC-I molecules, and therefore become susceptible to lysis [8]. According to the length of their cytoplasmatic tail KIR are classified into long (e.g., KIR2DL and KIR3DL), inhibitory, and short (e.g., KIR2DS and KIR3DS) stimulating receptors, although inhibitory KIRs are dominant [9].

In humans, $\mathrm{CD}^{-} \mathrm{CD}^{-} 6^{+} \mathrm{NK}$ cells can be subdivided in two functionally and phenotipically different subsets based on CD56 receptor expression. $\mathrm{CD}^{-} \mathrm{CD} 56^{\mathrm{dim}+}$ subset, that aside from high expression of inhibitory KIR receptors and CD16 activating receptor, also expresses abundant perforin and granzymes in their granules and is involved in NK cell cytotoxicity. The other $\mathrm{CD}^{-} \mathrm{CD} 56^{\text {bright+ }}$ subset, with low expression of CD16 and low to absent expression of KIR receptors has a regulatory function, owing to its abundant cytokine production and weak cytotoxicity [10].

As it is known that melanoma patients with advanced disease have impairments in their immune response, including decreased NK cell activity [11], and that melanoma is an immunogenic tumor resistant to chemotherapy and irradiation, immunomodulating agents such as cytokines have been included in its treatment [12]. In this sense, IFN- $\alpha$ and IL- 2 are administrated in the immunotherapy of melanoma for several decades [12,13]. On the other hand, considering that their therapeutic effects are limited, many other cytokines, such as IL-12 and IL-18 have been investigated in this disease $[14,15]$.

Interleukin-12 (IL-12) is a cytokine that is produced primarily by antigen-presenting cells and by enhancing NK and $\mathrm{T}$ cell cytotoxicity, inducing IFN- $\gamma$ production from these cells and favoriting Th1 differentiation plays an essential role in the interaction between the innate and adaptive immunity [16]. Interleukin-18 (IL-18) is an immunoregulatory and proinflammatory cytokine that belong to the IL-1 family. It shows numerous effects not only on NK cells, but also on monocytes, dendritic cells (DCs), T cells. IL-18 acts synergistically with IL-12 to promote cytotoxicity and IFN- $\gamma$ production from $\mathrm{NK}$ and $\mathrm{T}$ cells [17] and also it is involved in NK cell priming [18] and the interaction between DCs and NK cells [19].

As IL-12 and IL-18 have an important role in improving anti-tumor immune response they could have a great potential in cancer immunotherapy. We, therefore, consider that it is of interest to assess in vitro effects of IL-12, IL-18 and their combination on NK cell effector functions, cytotoxicity and IFN- $\gamma$ production, as well as on the expression of numerous receptors on NK cells and their dim and bright subsets in metastatic melanoma (MM) patients and healthy controls $(\mathrm{HC})$.

\section{Methods \\ Blood samples}

Peripheral venous blood was obtained from $36 \mathrm{MM}$ patients (stage IV according to $7^{\text {th }}$ modified AJCC/UICC staging system) [20] and $26 \mathrm{HC}$, age and gender matched, with no evidence of any disease or infection. Blood was drawn at the time of diagnosis prior to chemotherapy. Before inclusion in the study, informed consent was signed by each patient and healthy volunteer and approved by the Ethical committee of Institute of Oncology and Radiology of Serbia. The characteristics of MM patients and $\mathrm{HC}$ enrolled in this study are listed in Table 1. Furthermore, MM patients are divided in 2 groups based on the localization of distant metastases according to AJCC/ UICC staging system. Patients that have metastases in distant skin, the subcutaneous layer or in distant lymph nodes and normal values of serum lactate dehydrogenase $(\mathrm{LDH})(<460 \mathrm{IU} / \mathrm{l})(\mathrm{M} 1 \mathrm{a})$ and patients with metastases in 
Table 1 The characteristics of metastatic melanoma (MM) patients and healthy controls (HC)

\begin{tabular}{|c|c|c|c|}
\hline & & $\begin{array}{l}\mathrm{MM} \\
\mathrm{n}=\mathbf{2 6}\end{array}$ & $\begin{array}{l}\mathrm{HC} \\
\mathrm{n}=36\end{array}$ \\
\hline \multicolumn{4}{|l|}{ Age: } \\
\hline & Range & $36-67$ & $37-73$ \\
\hline & Median & 51 & 54 \\
\hline \multicolumn{4}{|l|}{ Gender: } \\
\hline & Male & 14 & 17 \\
\hline & Female & 12 & 19 \\
\hline \multicolumn{4}{|l|}{ Metastases: } \\
\hline & Distant skin & & 10 \\
\hline & Subcutaneous layer & & 7 \\
\hline & Distant lymph nodes: & & 16 \\
\hline & axillary & & 8 \\
\hline & inguinaly & & 7 \\
\hline & retroperitonealy & & 1 \\
\hline & Lungs & & 10 \\
\hline & Liver & & 10 \\
\hline & Spleen & & 3 \\
\hline & Suprarenal gland & & 4 \\
\hline & Bones & & 3 \\
\hline \multicolumn{4}{|l|}{ LDH serum values: } \\
\hline & normal (<460 IU/I) & & 20 \\
\hline & increased (>460 IU/I) & & 16 \\
\hline \multicolumn{4}{|l|}{$\begin{array}{l}\text { Classification of } \\
\text { distant metastases: }\end{array}$} \\
\hline & M1a & & 11 \\
\hline & M1b & & 7 \\
\hline & M1c & & 18 \\
\hline
\end{tabular}

the lungs (M1b) are included in M1a + M1b group, while the patients with metastases in vital organs other than the lungs with normal serum LDH level or the patients that have any distant metastasis with elevated LDH (>460 IU/l) are included in M1c group.

\section{Peripheral blood mononuclear cell (PBMC) isolation}

PBMC were isolated from heparinized blood obtained from $\mathrm{HC}$ and MM patients using Lymphoprep (Nypacon, Oslo, Norway) density gradient, centrifuged at $500 \mathrm{~g}$ for $40 \mathrm{~min}$, and washed three times in RPMI 1640 culture medium (CM), (Sigma, St. Louis, USA) supplemented with $10 \%$ fetal calf serum (FCS) (Sigma). After washing PBMC were immediately used for functional, phenotypic and molecular analysis.

\section{In vitro treatment of $\mathrm{PBMC}$ with various cytokines}

PBMC isolated from $\mathrm{HC}$ and MM patients were cultivated in $\mathrm{CM}$ alone, CM supplemented with IL-12 (10 ng/ml)
(Becton Dickinson, San Jose, USA), IL-18 (100 ng/ml) (R\&D, Minneapolis, USA) and IL-12 and IL-18 in combination, in six well plates at $37^{\circ} \mathrm{C}$ and $5 \% \mathrm{CO} 2$ in humid atmosphere.

\section{NK cell assay}

PBMC was determined using standard cytotoxicity assay [21]. One hundred microlitres of PBMC, as effector cells, at concentration of $4.0 \times 10^{6} / \mathrm{ml}$ of $\mathrm{CM}$ and two 1:1 dilutions were mixed with $100 \mu \mathrm{l}$ of the erythromyeloid cell line K562, as target cells, at concentration of $0.05 \times 10^{6} / \mathrm{ml}$, prelabeled with radioactive ${ }^{51} \mathrm{Chromium}$ $(\mathrm{Na} 2 \mathrm{CrO} 4, \mathrm{As}=3.7 \mathrm{MBq}$, Amersham, UK), to form triplicates of three effector cell $(\mathrm{E})$ to target cell $(\mathrm{T})$ ratios (E:T), 80:1, 40:1 and 20:1. The assay was performed in 96 round bottom microwell plates (Sigma), which were incubated in an incubator at $37^{\circ} \mathrm{C}$, in a humidified atmosphere containing $5 \% \mathrm{CO}_{2}$. Plates were, then centrifuged for $3 \mathrm{~min}$ at $200 \mathrm{~g}$ and the supernatant from each well was used for determination of the amount of released ${ }^{51}$ Chromium from the lysed K562 cells in a gamma counter (Berthold, Oak Ridge, USA) and expressed in counts per minute (cpm). The mean percent cytotoxicity was calculated using the following formula:

$$
\frac{\mathrm{cpm}(\text { experimental release })-\mathrm{cpm}(\text { spontaneous release })}{\mathrm{cpm}(\text { maximal release })-\mathrm{cpm}(\text { spontaneous release })} \times 100
$$

Maximal release was obtained by incubation of target K562 tumor cells at the same concentration in the presence of $5 \%$ TritonX-100, and spontaneous release was obtained by incubation of $\mathrm{K} 562$ cells in culture medium, alone.

\section{Flow cytometric analysis}

Surface immuno-phenotype of $18 \mathrm{~h}$ in vitro treated PBMC subsets were identified using the following combinations of directly labeled monoclonal antibodies (mAbs): CD3PerCP (clone SK7)/CD56FITC (clone NCAM 16.2)/IL-12Rbeta1PE (clone 2.4E6), CD3PerCP/CD56FITC/IL-12Rbeta2PE (clone 2B6/12 beta 2), CD3PerCP/CD56FITC/DNAM1PE (clone DX11), CD3PerCP/CD56FITC/CD161PE (clone DX12), CD3PerCP/CD56FITC/CD158bPE (clone CH-L), CD3PerCP/CD56PE (clone NCAM 16.2)/CD158aFITC (clone HP-3E4), CD3PerCP/CD56FITC/CD25PE (clone M-A251) (Becton Dickinson) and CD3PerCP/CD56FITC/ NKG2DPE (clone 149810) (R\&D). The samples were prepared as previously described [22]. Briefly, $1.0 \times 10^{5}$ PBMC in $100 \mu \mathrm{l}$ RPMI 1640 supplemented with $10 \%$ FCS were incubated for $30 \mathrm{~min}$ at $4^{\circ} \mathrm{C}$ with $20 \mu \mathrm{l}$ of appropriate mAbs combination, washed twice with icecold phosphate-buffered saline (PBS) and fixed with 1\% paraformaldehyde prior to flow cytometry analysis. Surface marker expression was quantified on FACSCalibur flow cytometer (Becton Dickinson). A total of 50000 
gated events, verified as PBL according to their physical characteristics (FSC and SSC), were collected per sample and analyzed using CellQUEST software. Exclusion of non-specific fluorescence was based on matched IgG1 isotype mAb combinations conjugated with FITC (clone X39), PE (clone X40) and PerCP (clone SK7) (Becton Dickinson). NK cells were defined and gated within the lymphocyte gate according to their expression of $\mathrm{CD} 3$ and $\mathrm{CD} 56\left(\mathrm{CD}^{-} \mathrm{CD}^{-} 6^{+}\right)$. In order to define the two NK cell subsets of $\mathrm{CD} 56$ low, i.e., $\mathrm{CD} 3^{-} \mathrm{CD} 56^{\mathrm{dim}+}$ or $\mathrm{CD} 56$ high, i.e., $\mathrm{CD}^{-} \mathrm{CD} 56^{\text {bright+ }}$ subsets, $\mathrm{CD}^{-} \mathrm{CD}^{-} 6^{+}$ NK cells were divided based on the density of CD56 antigen defined by mean fluorescence intensity (MFI). MFI refers to the fluorescence intensity of each event in average and represents the expression quantity of the parameter on each event. NK cell receptors, IL-12R beta 1, IL-12R beta 2, NKG2D, DNAM-1, CD161, CD158a, CD158b and CD25 were expressed as the percentage or MFI on gated $\mathrm{CD} 3^{-} \mathrm{CD} 56^{+} \mathrm{NK}$ cells and their $\mathrm{CD} 3^{-} \mathrm{CD} 56^{\mathrm{dim}+}$ and $\mathrm{CD}^{-}{ }^{-} \mathrm{CD} 56^{\text {bright+ }}{ }^{+} \mathrm{NK}$ cell subsets.

\section{107 degranulation assay}

$100 \mu \mathrm{l}$ of $18 \mathrm{~h}$ in vitro stimulated PBMC $\left(3 \times 10^{6} \mathrm{cells} / \mathrm{ml}\right)$ from $\mathrm{HC}$ and MM patients were cultured with $100 \mu \mathrm{l}$ of washed $\mathrm{K} 562\left(2 \times 10^{6} / \mathrm{ml}\right)$ for 4 hours at $37^{\circ} \mathrm{C}$ in a humidified atmosphere in $\mathrm{CO}_{2}$ incubator. Monensin (Sigma) at the final concentration of $2 \mu \mathrm{l} / \mathrm{ml}$ was added after 1 hour of incubation. Cells were afterwards stained with CD56FITC, CD107aPE (clone H4A3) and CD3PerCP mAbs (Becton Dickinson). The percentage and MFI of CD107a was estimated on gated $\mathrm{CD}^{-} \mathrm{CD}^{-} 6^{+} \mathrm{NK}$ cells, as well as on $\mathrm{CD}^{-}{ }^{-} \mathrm{CD} 56^{\mathrm{dim}+}$ and $\mathrm{CD} 3^{-} \mathrm{CD} 56^{\text {bright+ }}$ NK subsets by flow cytometry. Spontaneous CD107a expression was determined in absence of K562 cells.

\section{Intracellular IFN-gamma, phosphorylated STAT-4 and perforin analyses}

For measurement of phosphorylated pSTAT-4 $20 \mathrm{~min}$ and for measurement of IFN- $\gamma$ and perforin $18 \mathrm{~h}$ in vitro stimulated PBMC $\left(1 \times 10^{6} / \mathrm{ml}\right)$ from $\mathrm{HC}$ and MM patients were analyzed. Three hours before IFN- $\gamma$ analysis, brefeldin A was added at concentration of $10 \mu \mathrm{g} / \mathrm{ml}$. The cells were then stained with mAbs against cell surface molecules: CD3PerCP, CD56PE (for IFN- $\gamma$ analysis) and CD56FITC (for pSTAT-4 and perforin analyses) (Becton Dickinson), followed by fixing and permeabilizing with the Permeabilizing Solution 2 (Perm 2) (Becton Dickinson) accords to the manufacturer's instructions. Then the cells were incubated with anti-IFN- $\gamma$ FITC (clone 25723.11), anti-pSTAT-4PE (clone 38/p-Stata4) (Becton Dickinson), anti-Perforin RPE (clone deltaG9) (Invitrogen, Madison, USA) or IgG1 isotype control (Becton Dickinson). Finally, the cells were washed and analyzed by flow cytometry directly after preparation. The percentages and MFI of intracellular IFN- $\gamma$, pSTAT- 4 and perforin were analyzed in $\mathrm{CD}^{-} \mathrm{CD}^{-} 6^{+} \mathrm{NK}$ cells and their $\mathrm{CD}^{-} \mathrm{CD} 56^{\mathrm{dim}+}$ and $\mathrm{CD}^{-}{ }^{-} \mathrm{CD} 56^{\text {bright+ }}$ subsets.

\section{RT-PCR}

For the analysis of DAP10 transcription level total RNA was isolated from $18 \mathrm{~h}$ in vitro stimulated PBMC of $\mathrm{HC}$ and MM patients using Trizol reagent (Invitrogen). One microgram of total RNA was reverse transcribed by random priming, incubated with $1 \mu \mathrm{l}$ reverse transcriptase MuLV (Fermentas, St. Leon Rot, Germany), $10 \mathrm{mM}$ deoxynucleotide triphosphate mix (dNTP) (Fermentas), RNAse inhibitor (Fermentas) and $2 \mu \mathrm{l} 0.1 \mathrm{M}$ dithiothreitol (DTT) (Fermentas) for $1 \mathrm{~h}$ at $37^{\circ} \mathrm{C}$ and then $5 \mathrm{~min}$ at $99^{\circ} \mathrm{C}$. Total cDNA was then amplified by PCR with specific primers: DAP-10 (350 bp) (up: 5'-CAG ACC CCA GTC CAC CAT G-3' and down: 5'-GTG CCA CCA CAC ACC ATC-3') and beta-Actin as housekeeping gene (685 bp) (sense: 5' - TGG GTC AGA AGG ATT CCT AT-3' and antisense: 5' - AAG GAA GGC TGG AAG AGT - $3^{\prime}$ ). The optimal cycle conditions were $30 \mathrm{sec}$ at $94^{\circ} \mathrm{C}, 30 \mathrm{sec}$ at $55^{\circ} \mathrm{C}, 30 \mathrm{sec}$ at $72^{\circ} \mathrm{C}$ for 30 cycles. RTPCR results were analyzed on $1.5 \%$ agarose gels.

\section{Quantification of blots and gels}

Agarose gels were scanned by using gel-image system (Kodak Image 1D Image 1 3.6.), in a grey scale mode at $169 \mathrm{~mm}$ pixel size and 1250-1650 (X-Y) pixel count, using the autodensity feature on a scale ranging from 0 (clear) to 255 (opaque). The pixel density was determined and used to calculate the integrated density of a selected band. Values of integrated density were reported in volume units of pixel intensity per $\mathrm{mm}^{2}$.

\section{Statistical analysis}

Significance of differences for obtained results was done by nonparametric Wilcoxon signed rank test and MannWhitney exact test.

\section{Results}

The effect of investigated cytokines on NK cell cytotoxic activity and IFN- $\gamma$ production

We show that in both HC and MM patients NK cell cytotoxic activity performed against standard sensitive erythromyeloid K562 tumor target cell line after treatment with $10 \mathrm{ng} / \mathrm{ml}$ of IL-12 alone or in combination with IL-18 $(100 \mathrm{ng} / \mathrm{ml})$ is high significantly $(\mathrm{p}<0.01$, Wilcoxon signed rank test) enhanced, while after treatment with IL-18 alone is significantly ( $\mathrm{p}<0.05$, Wilcoxon signed rank test) augmented only in $\mathrm{HC}$ compared to the results in CM. Contrary to this, in investigated MM patients IL-18 alone does not significantly ( $p>0.05$, Wilcoxon signed rank test) potentiate NK cell activity (Figure 1a). 


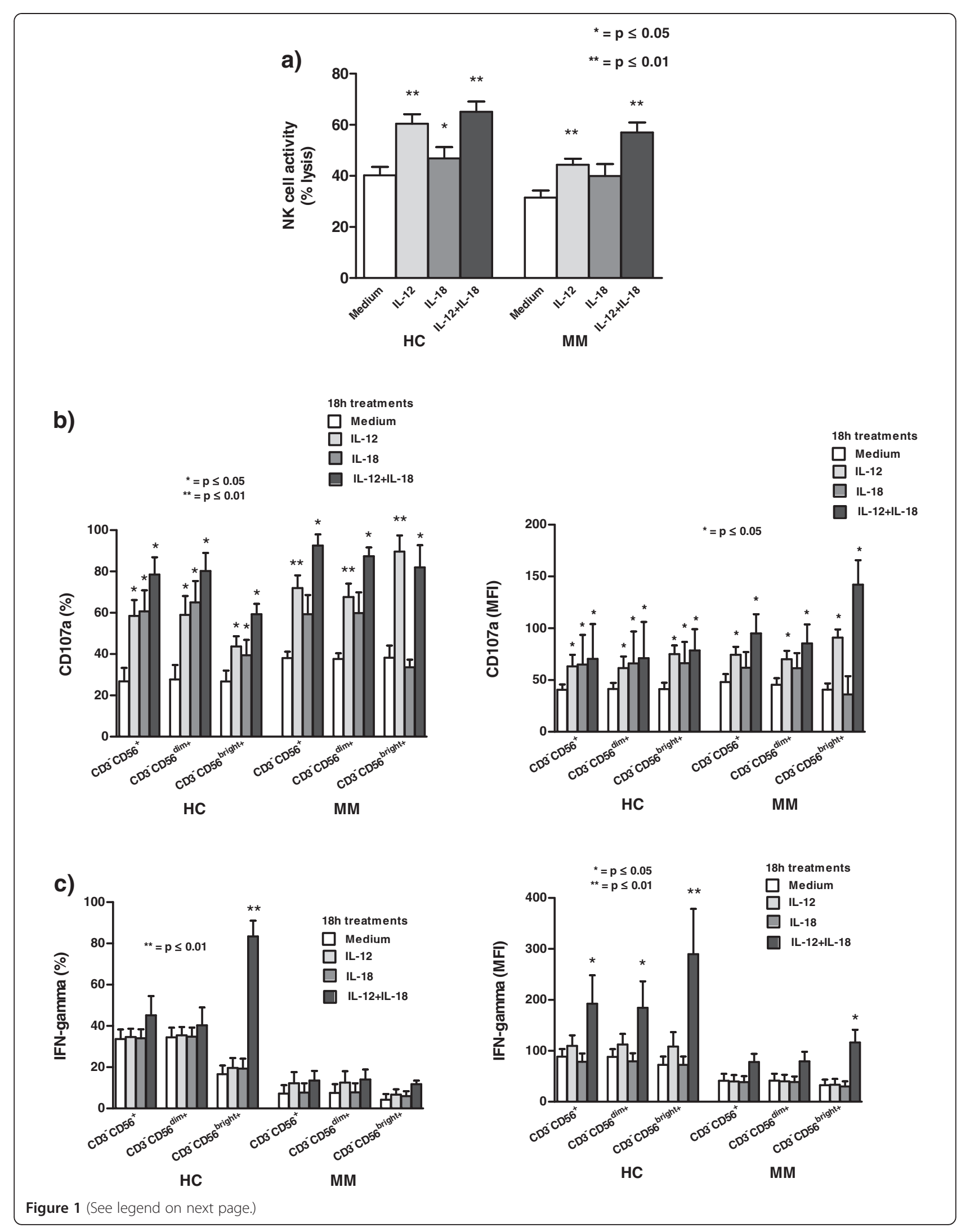


(See figure on previous page.)

Figure 1 The effect of cytokines on NK cell cytotoxic activity and IFN- - production. a) In healthy controls (HC) and metastatic melanoma (MM) patients high significant $\left({ }^{* *} \mathrm{p}<0.01\right.$, Wilcoxon signed rank test) enhancement of NK cell cytotoxicity is obtained after $18 \mathrm{~h}$ in vitro treatment of peripheral blood mononuclear cells (PBMC) with IL-12 alone $(10 \mathrm{ng} / \mathrm{ml})$, as well as with IL-12 in combination with IL-18 (100 $\mathrm{ng} / \mathrm{ml})$ that gives a significant ( ${ }^{*} p<0.05$, Wilcoxon signed rank test) increase in HC only; b) In both HC and MM patients IL-12 alone or in combination with IL-18 significantly $\left({ }^{*} p<0.05\right.$, Wilcoxon signed rank test) or high significantly $\left({ }^{* *} p<0.01\right.$, Wilcoxon signed rank test) increases the percentage and mean fluorescence intensity (MFI) of CD107a degranulation marker on $\mathrm{CD}^{-} \mathrm{CD}^{+} 6^{+} \mathrm{NK}$ cells and their $\mathrm{CD}^{-} \mathrm{CD}_{5} 6^{\text {dim+ }}$ and $\mathrm{CD}^{-} \mathrm{CD}^{2} 6^{\text {bright+ }}$ subsets, while IL-18 alone significantly ( ${ }^{*} \mathrm{p}<0.05$, Wilcoxon signed rank test) increases the expression of CD107a on NK cells and their subsets only in HC. Results are obtained by Flow cytometry; c) In HC 18 h in vitro treatment of PBMC with combination of IL-12 and IL-18 high significantly (**p $<0.01$, Wilcoxon signed rank test) increases the percentage of IFN- $\gamma$ only in the bright NK cell subset, while this combined cytokine treatment increases the MFI of IFN- $\gamma$ significantly $\left({ }^{*} p<0.05\right.$, Wilcoxon signed rank test) in NK cells and their dim subset and high significantly $\left({ }^{* *} p<0.01\right.$, Wilcoxon signed rank test) in the bright NK cell subset. In MM patients the combination of IL-12 and IL-18 significantly ( ${ }^{*} p<0.05$, Wilcoxon signed rank test) increases only the MFI of IFN- $\gamma$ in the bright subset. Results are obtained by Flow cytometry. All results are shown as mean \pm SE for maximum $26 \mathrm{HC}$ and $36 \mathrm{MM}$ patients.

Our results also indicate that in both $\mathrm{HC}$ and $\mathrm{MM}$ patients IL-12 alone or in combination with IL-18 significantly $(\mathrm{p}<0.05$, Wilcoxon signed rank test) or high significantly ( $\mathrm{p}<0.01$, Wilcoxon signed rank test) increases the percentage or MFI of CD107a degranulation marker on NK cells and both their dim and bright subsets. Contrary to this, IL-18 alone, compared to the results in CM, significantly ( $\mathrm{p}<0.05$, Wilcoxon signed rank test) increases the expression of CD107a only in HC (Figure 1b).

Furthermore, we analyze the production of intracellular IFN- $\gamma$ in NK cells and their dim and bright subsets in $\mathrm{HC}$ and $\mathrm{MM}$ patients after $18 \mathrm{~h}$ PBMC in vitro treatments with IL-12, IL-18 and their combination. We show that in HC, combined IL-12 and IL-18 treatment high significantly $(\mathrm{p}<0.01$, Wilcoxon signed rank test) increases the percentage of IFN- $\gamma$ only in the bright NK cell subset, while this cytokine treatment increases the MFI of IFN- $\gamma$ significantly $(\mathrm{p}<0.05$, Wilcoxon signed rank test) in NK cells and the dim subset and high significantly ( $p<0.01$, Wilcoxon signed rank test) in the bright NK cell subset. In MM patients the combination of IL-12 and IL-18 significantly ( $p<0.05$, Wilcoxon signed rank test) increases only the MFI of IFN- $\gamma$ in the bright subset. Contrary to this, IL-12 or IL-18 alone does not have any significant ( $p>0.05$, Wilcoxon signed rank test) effect on IFN- $\gamma$ production in NK cells and both their subsets in $\mathrm{HC}$, as well as in MM patients (Figure 1c).

\section{The effect of investigated cytokines on the percentages} and absolute values of NK cells and their subsets

All investigated cytokines do not have any significant effect ( $\mathrm{p}>0.05$, Wilcoxon signed rank test) on the percentages, as well as on the absolute values of NK cells and their dim and bright subsets in HC and MM patients (Table 2).

\section{The differences in cytokine-induced increase in NK cell activity between $\mathrm{M} 1 \mathrm{a}+\mathrm{M} 1 \mathrm{~b}$ and M1c metastatic melanoma patients}

We show that patients in M1c group have significantly ( $\mathrm{p}<0.05$, Mann-Whitney exact test) lower enhancement in NK cell cytotoxicity after in vitro treatment with combination of IL-12 and IL-18 compared to the increase in M1a + M1b group. IL-12 or IL-18 alone has the similar effect on the induction of NK activity in both groups of investigated MM patients (Figure 2a).

Furthermore, MM patients that have distant metastasis in liver have significantly $(\mathrm{p}<0.05$, Mann-Whitney exact test) or high significantly ( $\mathrm{p}<0.01$, Mann-Whitney exact test) lower enhancement in NK cell cytotoxicity after in vitro treatment with IL-12 alone or in combination with IL-18 compared to the increase in NK cell cytotoxicity in MM patients with distant metastases in skin, subcutaneous layer and lymph nodes. IL-18 alone has the similar effect on the induction of NK activity in all investigated groups of MM patients (Figure 2b).

MM patients with increased values of serum LDH $(\mathrm{LDH}+)$ have significantly lower $(\mathrm{p}<0.05$, Mann-Whitney exact test) upregulation of NK cell cytotoxicity after combined IL-12 and IL-18 in vitro treatment compared to patients with normal LDH values (LDH-) (Figure 2c).

\section{The differences in IL-12 receptor expression and cytokine-induced increase in PSTAT-4 and perforin expression in NK cells between M1a + M1b and M1c metastatic melanoma patients}

Furthermore, we show that MM patients that belong to M1c group have significantly $(\mathrm{p}<0.05$, Mann-Whitney exact test) lower expression of both IL-12R, IL-12R beta 1 and IL-12R beta 2, on their NK cells compared to patients in M1a + M1b group (Figure 3a).

Analyzing the influence of the investigated cytokines on pSTAT-4 signaling molecule expression in NK cells of MM patients by Flow cytometry we show that $20 \mathrm{~min}$ in vitro treatment with IL-12 increases this molecule MFI significantly ( $<<0.05$, Mann-Whitney exact test) lower in M1c group of patients compared to the increase in M1a + M1b group. IL-18 alone or in combination with IL-12 has the similar effect ( $p>0.05$, Wilcoxon signed rank test) on the induction of pSTAT-4 expression in NK cells in both groups of investigated MM patients (Figure $3 \mathrm{~b}$ ).

MFI of cytotoxic mediator, perforin, in NK cells is significantly $(\mathrm{p}<0.05$, Mann-Whitney exact test) lower 
Table 2 The percentages and absolute values of NK cell subsets after cytokine in vitro treatment

\begin{tabular}{|c|c|c|c|c|c|c|}
\hline & & \multicolumn{5}{|c|}{$18 \mathrm{~h}$ in vitro treatment } \\
\hline & & & Medium & IL-12 & IL-18 & IL-12 + IL-18 \\
\hline \multirow[t]{6}{*}{ Controls $(n=26)$} & Percentage (\%) & $\mathrm{CD}^{-} \mathrm{CD}^{-} 6^{+}$ & $13.76 \pm 1.75^{\#}$ & $14.58 \pm 2.67$ & $13.92 \pm 2.66$ & $12.47 \pm 2.14$ \\
\hline & & $\mathrm{CD} 3^{-} \mathrm{CD} 56^{\mathrm{dim}+}$ & $12.72 \pm 1.76$ & $13.39 \pm 2.64$ & $12.04 \pm 2.26$ & $11.53 \pm 2.13$ \\
\hline & & $\mathrm{CD}^{-} \mathrm{CD} 56^{\text {bright+ }}$ & $1.06 \pm 0.11$ & $1.18 \pm 0.15$ & $1.07 \pm 0.20$ & $0.90 \pm 0.12$ \\
\hline & Apsolute values $(/ \mu \mathrm{l})$ & $\mathrm{CD}^{-} \mathrm{CD}_{5} 6^{+}$ & $261.53 \pm 19.33$ & $280.53 \pm 29.33$ & $255.28 \pm 21.38$ & $275.14 \pm 23.33$ \\
\hline & & $\mathrm{CD} 3^{-} \mathrm{CD} 56^{\mathrm{dim}+}$ & $250.87 \pm 30.54$ & $260.71 \pm 32.55$ & $249.39 \pm 33.83$ & $259.12 \pm 35.22$ \\
\hline & & $\mathrm{CD}^{-} \mathrm{CD} 56^{\text {bright+ }}$ & $19.63 \pm 1.39$ & $21.13 \pm 0.19$ & $18.87 \pm 0.09$ & $20.18 \pm 1.01$ \\
\hline \multirow[t]{6}{*}{ Patients $(n=36)$} & Percentage (\%) & $\mathrm{CD}^{-} \mathrm{CD}_{5} 6^{+}$ & $16.61 \pm 1.99$ & $16.82 \pm 2.11$ & $17.70 \pm 2.42$ & $17.72 \pm 2.31$ \\
\hline & & $\mathrm{CD}^{-}{ }^{-\mathrm{CD}} 56^{\mathrm{dim}+}$ & $15.56 \pm 1.96$ & $15.82 \pm 2.10$ & $16.63 \pm 2.40$ & $16.66 \pm 2.29$ \\
\hline & & $\mathrm{CD}^{-} \mathrm{CD} 56^{\text {bright }+}$ & $1.05 \pm 0.09$ & $1.06 \pm 0.08$ & $1.07 \pm 0.10$ & $1.03 \pm 0.12$ \\
\hline & Apsolute values $(/ \mu \mathrm{l})$ & $\mathrm{CD}^{-} \mathrm{CD}^{-} 6^{+}$ & $328.32 \pm 21.33$ & $319.83 \pm 28.33$ & $319.83 \pm 25.13$ & $338.51 \pm 23.33$ \\
\hline & & $\mathrm{CD}^{-}{ }^{-} \mathrm{CD} 56^{\mathrm{dim}+}$ & $305.13 \pm 20.96$ & $300.75 \pm 39.73$ & $321.27 \pm 27.23$ & $325.17 \pm 27.71$ \\
\hline & & $\mathrm{CD}^{-}{ }^{-} \mathrm{CD} 56^{\text {bright+ }}$ & $22.87 \pm 0.19$ & $25.34 \pm 0.09$ & $26.13 \pm 0.33$ & $20.01 \pm 0.10$ \\
\hline
\end{tabular}

\#Results are expressed as mean values \pm SE. Absolute numbers were calculated by multiplying PBL number in the blood count with percentage for each subset obtained by flow cytometry.

upregulated after in vitro treatment with IL-12 alone or in combination with IL-18 in M1c group of patients compared to M1a + M1b group. Contrary to this, IL-18 alone has the similar effect on the induction of perforin expression in NK cells in both groups of patients ( $p>0.05$, Wilcoxon signed rank test) (Figure 3c).

The effect of investigated cytokines on the activating NKG2D, DNAM-1 and CD161 receptor expression on NK cells and their subsets

Analyzing the modulation of NKG2D activating receptor expression on $\mathrm{CD}^{-} \mathrm{CD}_{56}{ }^{+} \mathrm{NK}$ cells and their $\mathrm{CD}^{-}$ $\mathrm{CD} 56^{\text {dim+ }}$ and $\mathrm{CD}^{-} \mathrm{CD} 56^{\text {bright+ }}$ subsets with all investigated cytokines we show that both percentage and MFI of this receptor decrease significantly $(\mathrm{p}<0.05$, Wilcoxon signed rank test) only in MM patients after $18 \mathrm{~h}$ in vitro treatment with IL-18 on NK cells, as well as on their dim subset. IL-12 alone or in combination with IL-18 does not have any significant ( $p>0.05$, Wilcoxon signed rank test) effect on the expression of this NK cell receptor on NK cells, as well as on their subsets in $\mathrm{HC}$ and in MM patients (Figure 4a).

Analyzing the modulation of DAP10, NKG2D adaptor molecule, after $18 \mathrm{~h}$ cytokine treatments of PBMC in $\mathrm{HC}$, as well as in MM patients, we show that IL-18 alone high significantly $(\mathrm{p}<0.01$, exact Wilcoxon signed rank test) decreases mRNA level of this signaling molecule only in MM patients (Figure 4b).

Analyzing the expression of DNAM-1 on NK cells and their subsets, we show that, compared to treatment in $\mathrm{CM}$, the MFI of this receptor does not change significantly ( $\mathrm{p}>0.05$, Wilcoxon signed rank test) after $18 \mathrm{~h}$ in vitro treatments with all investigated cytokines in $\mathrm{HC}$, as well as in MM patients (Figure 4c).

Obtained results from activating NK cell receptor, CD161, show that in HC IL-12 alone or in combination with IL-18 significantly ( $\mathrm{p}<0.05$, Wilcoxon signed rank test) or high significantly $(\mathrm{p}<0.01$, Wilcoxon signed rank test) increases MFI of this receptor on NK cells and their subsets. Contrary to this, in MM patients the investigated cytokines do not have any significant $(p>0.05$, Wilcoxon signed rank test) effect on CD161 expression on NK cells and both dim and bright subsets (Figure 4d).

The effect of investigated cytokines on the inhibitory KIR, CD158a and CD158b, receptor expression on NK cells and their subsets

Analyzing the expression of KIR receptor, CD158a, on NK cells and their $\mathrm{CD}^{-} \mathrm{CD} 56^{\mathrm{dim}+}$ and $\mathrm{CD} 3^{-} \mathrm{CD} 56^{\text {bright+ }}$ subsets, we show that, compared to treatment in $\mathrm{CM}$, the percentage and MFI of this receptor do not change significantly ( $p>0.05$, Wilcoxon signed rank test) after $18 \mathrm{~h}$ in vitro treatments with all investigated cytokines in $\mathrm{HC}$, as well as in MM patients (Figure 5a).

Furthermore, contrary to the percentage expression of the other inhibitory KIR, CD158b, the MFI of this receptor decreases significantly $(\mathrm{p}<0.05$, Wilcoxon signed rank test) after $18 \mathrm{~h}$ in vitro treatment with combined IL-12 and IL-18 on NK cells and their dim subset in both $\mathrm{HC}$ and MM patients. IL-12 or IL-18 alone does not have any significant effect $(p>0.05$, Wilcoxon signed rank test) on CD158b expression on NK cells and their subsets in $\mathrm{HC}$ and in MM patients (Figure 5b). 


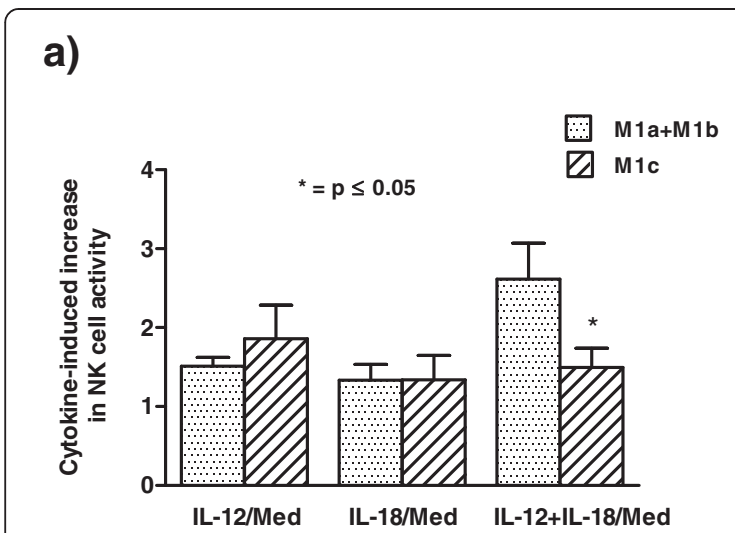

b)

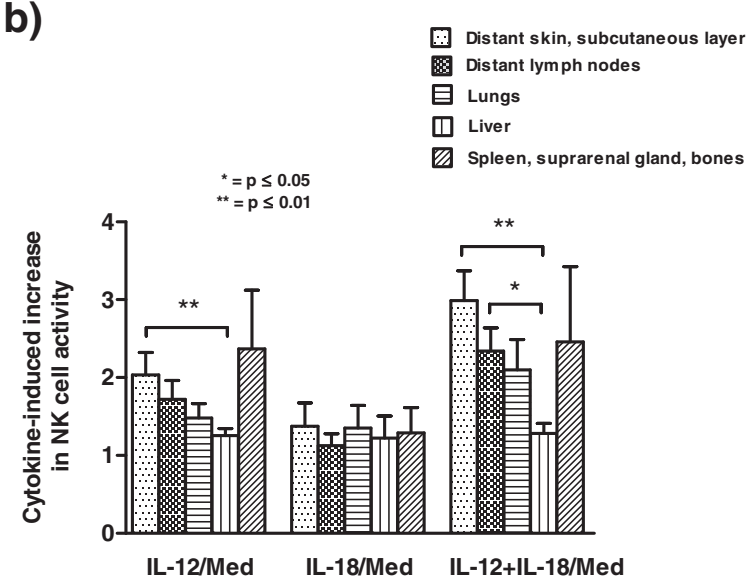

c)

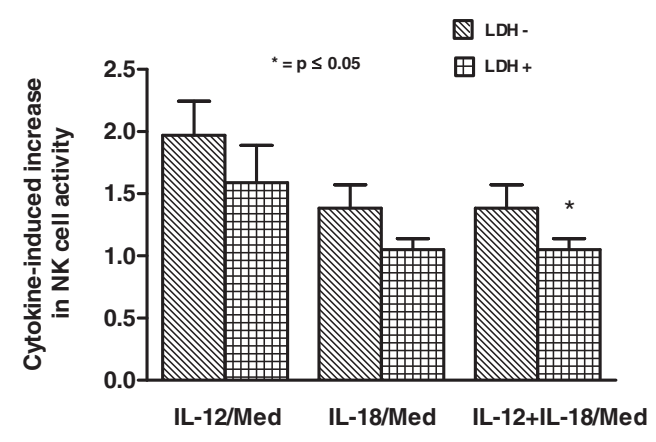

Figure 2 Cytokine-induced increase in NK cell activity in M1a + M1b and M1c metastatic melanoma patients. a) Patients in M1c group have significantly ( ${ }^{*} p<0.05$, Mann-Whitney exact test) lower enhancement in NK cell cytotoxicity after in vitro treatment with combination of $\mathrm{IL}-12$ and IL-18 compared to the increase in $\mathrm{M} 1 \mathrm{a}+\mathrm{M} 1 \mathrm{~b}$ group; b) Metastatic melanoma (MM) patients that have distant metastasis in liver have significantly $\left({ }^{*} p<0.05\right.$, Mann-Whitney exact test) or high significantly ${ }^{* *} p<0.01$, Mann-Whitney exact test) lower enhancement in NK cell cytotoxicity after in vitro treatment with IL-12 alone or in combination with IL-18 compared to the increase in NK cell cytotoxicity in MM patients with metastases in skin, subcutaneous layer and lymph nodes; c) MM patients with increased values of serum lactate dehydrogenase $(\mathrm{LDH}+)$ have significantly lower $\left({ }^{*} \mathrm{p}<0.05\right.$, Mann-Whitney exact test) upregulation of NK cell cytotoxicity after combined IL-12 and IL-18 in vitro treatment compared to patients with normal $\mathrm{LDH}$ values (LDH-). Results are expressed in indexes calculated as the value of NK cell cytotoxicity after the cytokine treatment of each MM patient devides with the value of NK cell cytotoxicity after treatment in medium alone. All results are shown as mean \pm SE for maximum $36 \mathrm{MM}$ patients.

The effect of investigated cytokines on CD25 receptor expression on NK cells and their subsets

Analyzing the expression of CD25 receptor we show that both percentage and MFI of this receptor increase significantly ( $\mathrm{p}<0.05$, Wilcoxon signed rank test) on $\mathrm{NK}$ cells and their dim and bright subsets in HC and MM patients after $18 \mathrm{~h}$ in vitro treatment with IL-12 and IL-18 in combination. IL-12 or IL-18 alone does not have any significant ( $p>0.05$, Wilcoxon signed rank test) effect on the expression of CD25 on NK cells and their subsets in $\mathrm{HC}$ and in MM patients (Figure 6a).

We also show that $\mathrm{HC}$ and MM patients that belong to $\mathrm{M} 1 \mathrm{a}+\mathrm{M} 1 \mathrm{~b}$ group have significantly $(\mathrm{p}<0.05$, MannWhitney exact test) higher increase in CD25 receptor expression on NK cells after in vitro treatment with combined IL-12 and IL-18 compared to the increase in M1c group (Figure 6b).

\section{Discussion}

In this study we demonstrate that NK cell cytotoxicity and the expression of CD107a degranulation marker on NK cells and both their subsets in $\mathrm{HC}$ are high significantly augmented by the performed in vitro treatments with IL-12, alone, or IL-12 and IL-18 in combination that is in accord with the existing data [23-25]. It is well known that these cytokines upon binding to their high affinity receptors increase cytotoxicity of NK cells by inducing perforin, granzymes, FasL, TRAIL gene transcription either directly or indirectly by various STAT transcription factors [26].

The role of IL-18 in regulating NK cell activity in healthy individuals and especially in cancer patients is still very controversial. The lower effect of this cytokine on the increase of NK cell cytotoxicity in $\mathrm{HC}$ may be due to low, but detectable level of IL-1Rrp, a component of the IL-18R on 


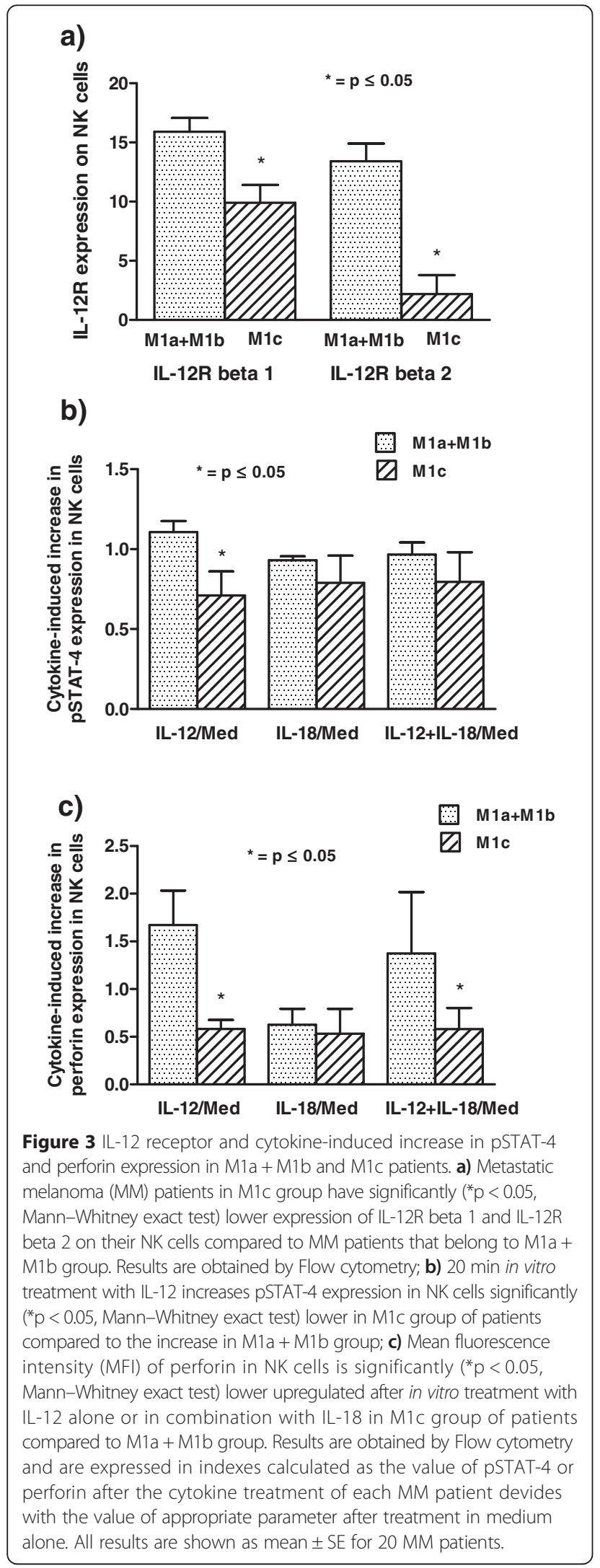

native NK cells. The potentiation of NK cell cytotoxicity when IL-18 is combined with IL-12 may also be associated with this receptor as it has been shown that this receptor is up-regulated by IL-12 or IL-15 stimulation [27]. Furthermore, we show for the first time that in MM patients IL-18 alone does not have any significant effect on NK cell cytotoxic function and CD107a expression on NK cells and their subsets. It has been shown in new experimental melanoma models that IL-18 may convert conventional Kit ${ }^{-}$ into $\mathrm{Kit}^{+} \mathrm{NK}$ cells that have immunosuppressive role [28].

Furthermore, as we show in this study that no one of investigated cytokine has the effect on the percentages, as well as the absolute values of NK cells and their dim and bright subsets in peripheral blood of $\mathrm{HC}$ and $\mathrm{MM}$ patients, the shown enhancement in NK cell cytotoxic function after in vitro cytokine treatment is not the consequence of increased number of investigated NK cells.

As it is well known that IL-12 and IL-18 have pronounced synergy in eliciting IFN- $\gamma$ secretion from NK cells [29], we show that contrary to significantly induced MFI of IFN- $\gamma$ in the entire population of cells, especially in $\mathrm{CD}_{5} 6^{\text {bright+ }}$ subset in $\mathrm{HC}$, in MM patients only the bright subset produces significantly higher level of IFN- $\gamma$ after combined IL-12 and IL-18 stimulation. Furthermore, we show that the level of this induction in the bright NK cell subset is significantly lower in MM patients compared to HC (data not shown). In this sense, we suggest that the other main effector function of NK cells, their immunoregulatory role, is suppressed in MM patients.

It is well known that in MM patients, the sites of metastases and serum levels of LDH are used to delineate these patients into three M categories: M1a, M1b, and M1c [20]. We show for the first time that the patients belonging to M1c category especially those patients that have distant metastasis in liver, as well as have increased level of serum LDH have significantly lower increase in NK cell cytotoxicity after in vitro treatment with combined IL-12 and IL-18 compared to the patients in M1a + M1b group that have metastases in distant skin, subcutaneous layer, lymph nodes and normal LDH serum values. These new data may suggest that contrary to MM patients that belong to M1c category with liver metastasis and elevated LDH, patients in M1a and M1b categories may be the target group for combined IL-12 and IL-18 treatment.

Furthermore, we show for the first time that MM patients that belong to M1c category have decreased expression of both IL-12 receptor subunits, IL-12R beta 1 and IL-12R beta 2 , on their NK cells. It is well known that binding to IL-12R beta 1 and through IL-12R beta 2, IL-12 activates JAK-STAT signaling molecules, primarily STAT-4, and regulating perforin level enhances NK and $\mathrm{T}$ cell cytotoxicity [16]. Thus, decreased IL-12R beta 


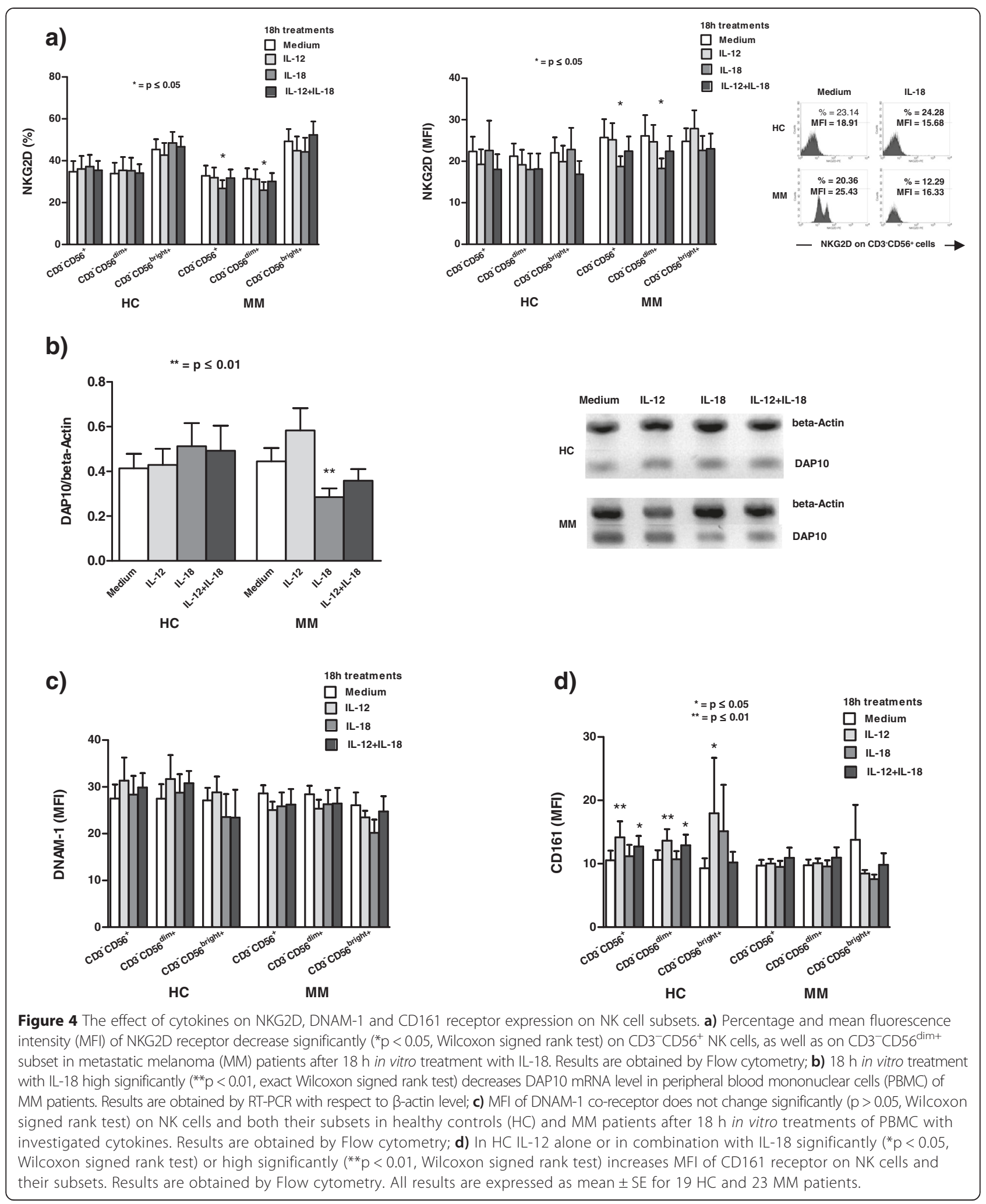

1 and IL-12R beta 2 expression on NK cells in M1c patients is in association with lower increase in pSTAT-4. and perforin expression in NK cells of these patients after IL-12 and combined IL-12 and IL-18 in vitro treatment shown in this study. In this sense, these new data may suggest, in M1c patients, the alteration in IL-12 


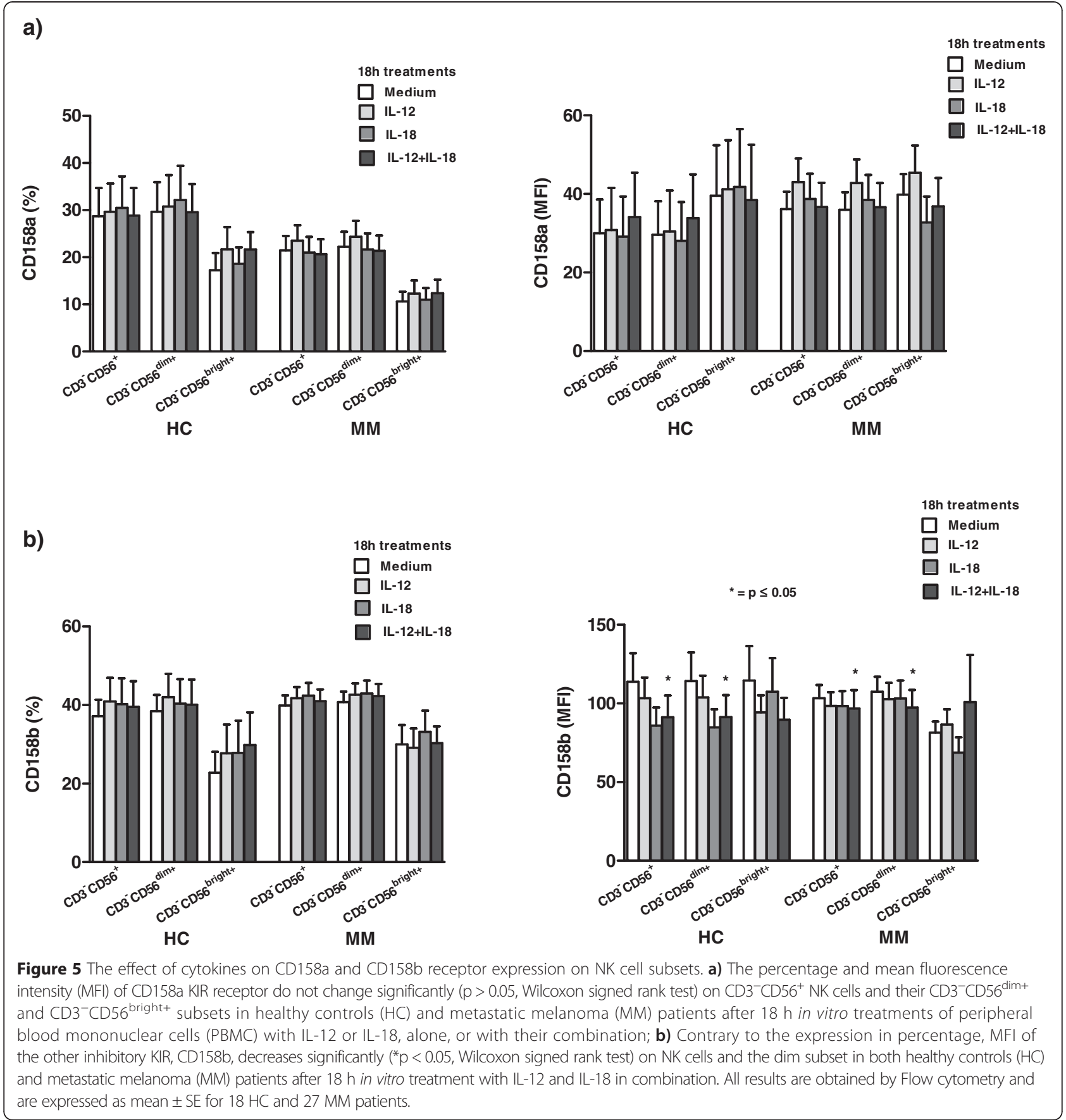

signaling in their NK cells, as well as lower NK cell response to IL-12 or IL-12 and IL-18 in combination, the potential immunotherapy of MM patients.

In this study we also give results regarding the influence of this newer generation of cytokines on NK cell receptor expression.

We show for the first time that in MM patients IL-18 significantly decreases the expression of activating NKG2D receptor on NK cells and their cytotoxic dim subset. This result may explain inactiveness of IL-18 in increase of NK cell cytotoxicity in MM patients obtained in this study. Some clinical observations show that high serum levels of IL-18 in cancer patients may be associated with various NK cell defects [30,31], as well as that this cytokine may have the role in melanoma metastases [32]. So downregulation of NKG2D after IL-18 in vitro treatment shown in this study could facilitate escape of melanoma cells from NKG2D-mediated killing by NK cells.

Furthermore, we show for the first time that IL-18 decreases mRNA level of DAP10, NKG2D receptor signaling 


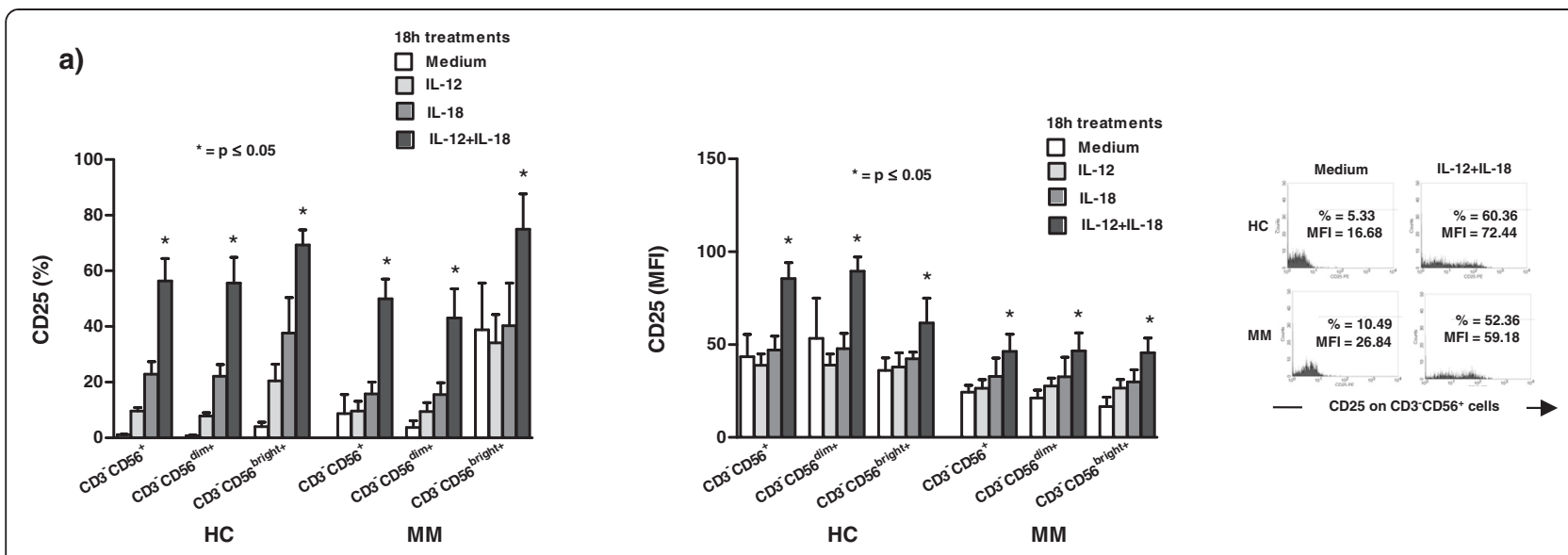

b)

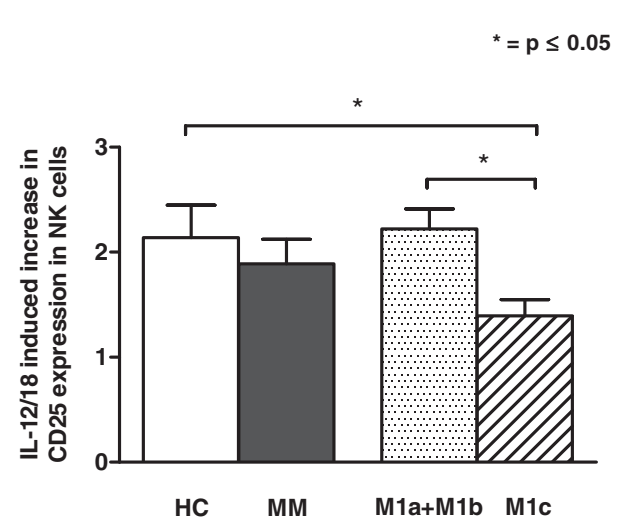

Figure 6 The effect of cytokines on CD25 receptor expression on NK cell subsets. a) The percentage and mean fluorescence intensity (MFI) of CD25 receptor increase significantly $\left({ }^{*} \mathrm{p}<0.05\right.$, Wilcoxon signed rank test) on $\mathrm{CD}^{-} \mathrm{CD}_{5} 6^{+} \mathrm{NK}$ cells and their $\mathrm{CD}^{-} \mathrm{CD}^{-\mathrm{dim}+}{ }^{\text {and }} \mathrm{CD} 3^{-} \mathrm{CD} 56^{\text {bright+ }}$ subsets in $\mathrm{HC}$ and MM patients after $18 \mathrm{~h}$ in vitro treatment with IL-12 and IL-18 in combination. Results are obtained by Flow cytometry; b) HC and MM patients in M1a + M1b group have significantly ( ${ }^{*} p<0.05$, Mann-Whitney exact test) higher increase in CD25 receptor expression on NK cells after in vitro treatment with combination of IL-12 and IL-18 compared to the increase in M1c group. Results are expressed in indexes calculated as the value of CD25 receptor expression after combined IL-12 and IL-18 treatment of each HC or MM patient devides with the value of this receptor expression after treatment in medium alone.

molecule, in PBMC of MM patients. Although DAP10 contributes not only to NK cells but also to CD8+ cytotoxic $\mathrm{T}$ lymphocytes (CTL)-mediated cytotoxicity via NKG2D receptor [33], in our experimental data we did not obtain the downregulation of NKG2D receptor on CTL after IL-18 in vitro PBMC treatment (data not shown). Therefore, decreased level of DAP10 in MM patients shown in this study could be associated with decreased NKG2D expression on NK cells and their dim subset in MM patients after IL-18 in vitro treatment. So far, there are no data regarding the effect of IL-12 and IL-18 on DAP10 level in NK cells and their subsets in MM patients.

As we show in this study that IL-12, IL-18 and their combination do not have any significant in vitro effect on DNAM-1 expression on NK cells and their subsets in $\mathrm{HC}$, as well as in MM patients it is possible that DNAM-1 receptor expression on NK cells is not only the cytokine but also experimental conditions-dependent that is in accord with a few data in literature $[34,35]$.

Furthermore, according to this study, IL-12 alone or in combination with IL-18 significantly increases CD161 expression on NK cells and their subsets only in HC. It is well known that the expression of CD161 is upregulated specifically by IL-12 [36]. The new results obtained in this study show that IL-12-induced CD161 activating receptor upregulation on NK cells and their subsets in $\mathrm{HC}$, could be associated with this cytokine-increased NK cell cytotoxicity.

The data regarding the effect of cytokines on KIR expression in cancer patients are very rare [37]. It is now known that KIR downregulation could indicate a state of NK cell hyporesponsiveness [38]. In this sense, our new results regarding IL-12 and IL-18 in vitro effect on KIR expression could indicate that in $\mathrm{HC}$ and MM patients combined IL-12 and IL-18 treatment by decreasing 
CD158b receptor MFI on NK cells and cytotoxic dim subset regulates NK cell responsiveness and effector function. On the other hand, the observations obtained in this study may suggest the existence of cytokinespecific mechanisms of NK cell receptor expression regulation that is important in the maintenance of NK cell cytolytic machinery.

In this study we show for the first time that only combined IL-12 and IL-18 treatment significantly increases CD25, $\alpha$ chain of IL-2 receptor, on NK cells and both their subsets in $\mathrm{HC}$, as well as in MM patients resulting in a constitution of functional high-affinity IL-2R (IL$2 \mathrm{R} \alpha \beta \gamma$ ). However, we show that $\mathrm{HC}$ and MM patients that belong to $\mathrm{M} 1 \mathrm{a}+\mathrm{M} 1 \mathrm{~b}$ group have significantly higher increase in $\mathrm{CD} 25$ receptor expression after in vitro combined IL-12 and IL-18 treatment compared to the patients in M1c group. Recent data regarding mice in vivo and human healthy in vitro models show that IL-12, IL-15 and IL-18 preactivated NK cells express high level of CD25, proliferate rapidly and have enhanced effector functions especially IFN- $\gamma$ production after stimulation with IL-2 [39]. Furthermore, these NK cells and their subsets are long-lived and might have memory-like properties [40,41]. Our new results suggest that adoptive transfer of IL-12 and IL-18 preactivated NK cells simultaneously treated with exogenous low dose of IL-2 may have an important place in immunotherapy of metastatic melanoma patients especially those patients belonging to M1a and M1b categories that have better survival outcome and prognosis.

\section{Conclusions}

In this study we give insight into novel activation mechanisms of NK cells in $\mathrm{HC}$ and MM patients that underlie the effects of cytokines, IL-12, IL-18 and their combination. There are rare data about the role of these cytokines in the regulation of NK cell effector functions and the expression of various activating and inhibitory receptors on these cells and their dim and bright subsets in MM patients. Based on our new results, we suggest that in vitro treatment with IL-12 and IL-18, in combination, compared to IL-12 and IL-18 treatment, alone, have a prominent effect on NK cell cytotoxicity, IFN- $\gamma$ production and the expression of CD25 receptor on NK cells in MM patients and especially in HC. Furthermore, MM patients that belong to M1c group especially those patients that have metastasis in liver and increased LDH serum values have significantly lower increase in NK cell cytotoxicity after in vitro treatment with IL-12 and IL-18 in combination compared to the patients that belong to $\mathrm{M} 1 \mathrm{a}+\mathrm{M} 1 \mathrm{~b}$ group. These results could be explained by decreased IL-12R beta 1 and IL-12R beta 2 expression on NK cells in M1c patients that is in association with lower increase in pSTAT-4 and perforin expression in
NK cells of these patients after IL- 12 and combined IL12 and IL-18 in vitro treatment found for the first time in this study. So therapeutic strategies based on the adoptive transfer of IL-12 and IL-18 in combination preactivated NK cells might have an important place in immunotherapy of metastatic melanoma patients with better survival outcome and prognosis.

\section{Abbreviations \\ IL: Interleukin; IFN: Interferon; NKG2D: Natural killer group 2, member D; STAT: Signal tranducers and activators of transcription; MHC: Major histocompatibility complex; RT-PCR: Reverse transcriptase-polymerase chain reaction; FITC: Fluorescein isothiocyanate; PE: Phycoerythrin.}

\section{Competing interests}

The authors declare that they have no competing interests.

\section{Authors' contributions}

KMM contributed to collection of information, analysis and interpretation of data and writing of the manuscript. NB and SM contributed to collection of information. RDz contributed to revision of the manuscript. VJ participated in design of the study and helped draft the manuscript. GK contributed to design and coordination of the study and revision of the manuscript. All authors read and approved the final manuscript.

\section{Acknowledgments}

This work was supported by the grants of the Ministry of Education, Science and Technological Development of the Republic of Serbia, numbers III41031 and 175056. We wish to thank Mrs. Jasna Popović Basić and Mrs. Miroslava Ćulafić for excellent technical work and help during this investigation and Mrs. Dušica Gavrilović for extensive statistical analyses.

\section{Author details}

'Department of Experimental Oncology, Institute of Oncology and Radiology of Serbia, Pasterova 14, 11000 Belgrade, Serbia. ${ }^{2}$ Department of Medical Oncology, Institute of Oncology and Radiology of Serbia, Pasterova 14, 11000 Belgrade, Serbia. ${ }^{3}$ Surgical Oncology Clinic, Institute of Oncology and Radiology of Serbia, Pasterova 14, 11000 Belgrade, Serbia. ${ }^{4}$ School of Medicine, University of Belgrade, Dr Subotića 8, 11000 Beograd, Serbia. ${ }^{5}$ Faculty of Medical Sciences, University of Kragujevac, P.BOX 124, 34000 Kragujevac, Serbia.

Received: 4 December 2014 Accepted: 30 March 2015 Published online: 14 April 2015

\section{References}

1. Campbell KS, Hasegawa J. Natural killer cell biology: an update and future directions. J Allergy Clin Immunol. 2013;132:536-44.

2. Alter G, Malenfant JM, Altfeld M. CD107a as a functional marker for the identification of natural killer cell activity. J Immunol Methods. 2004;294:15-22.

3. Moretta L, Pietra G, Montaldo E, Vacca P, Pende D, Falco M, et al. Human NK cells: from surface receptors to the therapy of leukemias and solid tumors. Front Immunol. 2014;5:87.

4. Ullrich E, Koch J, Cerwenka A, Steinle A. New prospects on the NKG2D/ NKG2DL system for oncology. Oncoimmunology. 2013;2, e26097.

5. López-Soto A, Huergo-Zapico L, Acebes-Huerta A, Villa-Alvarez M, Gonzalez S. NKG2D signaling in cancer immunosurveillance. Int J Cancer. 2015;136:1741-150.

6. de Andrade LF, Smyth MJ, Martinet L. DNAM-1 control of natural killer cells functions through nectin and nectin-like proteins. Immunol Cell Biol. 2014;92:237-44.

7. Kirkham CL, Carlyle JR. Complexity and diversity of the NKR-P1:Clr (Klrb1: Clec2) recognition systems. Front Immunol. 2014;5:214.

8. Kiessling R, Klein E, Wigzell H. "Natural" killer cells in the mouse. I. Cytotoxic cells with specificity for mouse moloney leukemia cells. Specificity and distribution according to genotype. Eur J Immunol. 1975;5:112-7.

9. Rajalingam R. Overview of the killer cell immunoglobulin-like receptor system. Methods Mol Biol. 2012;882:391-414. 
10. Cooper MA, Fehniger TA, Caligiuri MA. The biology of human natural killer-cell subsets. Trends Immunol. 2001;22:633-40.

11. Mirjačić Martinović KM, Babović NL, Džodić RR, Jurišić VB, Tanić NT, Konjević GM. Decreased expression of NKG2D, NKp46, DNAM-1 receptors, and intracellular perforin and STAT-1 effector molecules in NK cells and their dim and bright subsets in metastatic melanoma patients. Melanoma Res. 2014;24:295-304.

12. Shimanovsky A, Jethava A, Dasanu CA. Immune alterations in malignant melanoma and current immunotherapy concepts. Expert Opin Biol Ther. 2013;13:1413-27.

13. Alatrash G, Jakher H, Stafford PD, Mittendorf EA. Cancer immunotherapies, their safety and toxicity. Expert Opin Drug Saf. 2013;12:631-45.

14. Lasek W, Zagożdżon R, Jakobisiak M. Interleukin 12: still a promising candidate for tumor immunotherapy? Cancer Immunol Immunother 2014:63:419-35.

15. Srivastava S, Salim N, Robertson MJ. Interleukin-18: biology and role in the immunotherapy of cancer. Curr Med Chem. 2010;17:3353-7.

16. Wang Y, Fan KT, Li JM, Waller EK. The regulation and activity of interleukin-12. Front Biosci (Schol Ed). 2012:4:888-99.

17. Novick D, Kim S, Kaplanski G, Dinarello CA. Interleukin-18, more than a Th1 cytokine. Semin Immunol. 2013;25:439-48.

18. Chaix J, Tessmer MS, Hoebe K, Fuséri N, Ryffel B, Dalod M, et al. Cutting edge: priming of NK cells by IL-18. J Immunol. 2008;181:1627-31.

19. Chijioke $O$, Münz C. Dendritic cell derived cytokines in human natural killer cell differentiation and activation. Front Immunol. 2013:4:365.

20. Balch CM, Gershenwald JE, Soong SJ, Thompson JF, Atkins MB, Byrd DR, et al. AJCC melanoma staging and classification. J Clin Oncol. 2009;2009(27):6199-206.

21. Brown RL, Ortaldo JR, Griffith RL, Blanca I, Rabin H. The proliferation and function of human mononuclear leukocytes and natural killer cells in serum-free medium. J Immunol Methods. 1985;81:207-14.

22. Jackson A, Warner N. Preparation, staining and analysis by flow cytometry of peripheral blood leukocytes. In: Rose N, Friedmah H, Fahey J, editors. Manual of clinical laboratory immunology. 3rd ed. Washington DC: American Society for Microbiology; 1986. p. 226-35.

23. Lauwerys BR, Renauld JC, Houssiau FA. Synergistic proliferation and activation of natural killer cells by interleukin 12 and interleukin 18. Cytokine. 1999;11:822-30

24. Singh SM, Yanagawa H, Hanibuchi M, Miki T, Okamura H, Sone S. Augmentation by interleukin-18 of MHC-nonrestricted killer activity of human peripheral blood mononuclear cells in response to interleukin-12. Int J Immunopharmacol. 2000;22:35-43.

25. Heidemann SC, Chavez V, Landers CJ, Kucharzik T, Prehn JL, Targan SR. TL1A selectively enhances IL-12/IL-18-induced NK cell cytotoxicity against NK-resistant tumor targets. J Clin Immunol. 2010;30:531-8.

26. Zwirner NW, Domaica $\mathrm{Cl}$. Cytokine regulation of natural killer cell effector functions. Biofactors. 2010;36:274-88.

27. Fehniger TA, Shah MH, Turner MJ, VanDeusen JB, Whitman SP, Cooper MA et al. Differential cytokine and chemokine gene expression by human NK cells following activation with IL-18 or IL-15 in combination with IL-12: implications for the innate immune response. J Immunol. 1999;162:4511-20.

28. Terme M, Ullrich E, Aymeric L, Meinhardt K, Coudert JD, Desbois M, et al. Cancer-induced immunosuppression: IL-18-elicited immunoablative NK cells. Cancer Res. 2012;72:2757-67.

29. Schroder K, Hertzog PJ, Ravasi T, Hume DA. Interferon-gamma: an overview of signals, mechanisms and functions. J Leukoc Biol. 2004;75:163-89.

30. Shibatomi K, Ida H, Yamasaki S, Nakashima T, Origuchi T, Kawakami A, et al. A novel role for interleukin-18 in human natural killer cell death: high serum levels and low natural killer cell numbers in patients with systemic autoimmune diseases. Arthritis Rheum. 2001:44:884-926.

31. Mazodier K, Marin V, Novick D, Farnarier C, Robitail S, Schleinitz N, et al. Severe imbalance of IL-18/IL-18BP in patients with secondary hemophagocytic syndrome. Blood. 2005;106:3483-97.

32. Dinarello CA. The paradox of pro-inflammatory cytokines in cancer. Cancer Metastasis Rev. 2006:25:307-13.

33. Lanier LL. DAP10- and DAP12-associated receptors in innate immunity. Immunol Rev. 2009:227:150-60.

34. da Silva RF, Petta CA, Derchain SF, Alici E, Guimarães F. Up-regulation of DNAM-1 and NKp30, associated with improvement of NK cells activation after long-term culture of mononuclear cells from patients with ovarian neoplasia. Hum Immunol. 2014:75:777-84.
35. Chan CJ, Andrews DM, McLaughlin NM, Yagita H, Gilfillan S, Colonna M, et al. DNAM-1/CD155 interactions promote cytokine and NK cell-mediated suppression of poorly immunogenic melanoma metastases. J Immunol. 2010;184:902-11.

36. Azzoni L, Zatsepina O, Abebe B, Bennett IM, Kanakaraj P, Perussia B. Differential transcriptional regulation of CD161 and a novel gene, 197/15a, by IL-2, IL-15, and IL-12 in NK and T cells. J Immunol. 1998;161:3493-500.

37. Al Omar SY, Marshall E, Middleton D, Christmas SE. Increased killer immunoglobulin-like receptor expression and functional defects in natural killer cells in lung cancer. Immunology. 2011;133:94-104.

38. Orr MT, Lanier LL. Natural killer cell education and tolerance. Cell. 2010;142:847-56

39. Ni J, Miller M, Stojanovic A, Garbi N, Cerwenka A. Sustained effector function of IL-12/15/18-preactivated NK cells against established tumors. J Exp Med. 2012;209:2351-65.

40. Romee R, Schneider SE, Leong JW, Chase JM, Keppel CR, Sullivan RP, et al. Cytokine activation induces human memory-like NK cells. Blood. 2012;120:4751-60

41. Leong JW, Chase JM, Romee R, Schneider SE, Sullivan RP, Cooper MA, et al, Preactivation with IL-12, IL-15, and IL-18 induces CD25 and a functional high-affinity IL-2 receptor on human cytokine-induced memory-like natural killer cells. Biol Blood Marrow Transplant. 2014:20:463-73.

\section{Submit your next manuscript to BioMed Central and take full advantage of:}

- Convenient online submission

- Thorough peer review

- No space constraints or color figure charges

- Immediate publication on acceptance

- Inclusion in PubMed, CAS, Scopus and Google Scholar

- Research which is freely available for redistribution 